\title{
Kualitas Hidup Anak dengan Penyakit Jantung
}

\section{Quality of Life in Children with Heart Disease}

\author{
Ariani $^{1}$, Rina Yuda Novira ${ }^{2}$, Mardhani Yosoprawoto ${ }^{1}$ \\ ${ }^{1}$ Laboratorium IImu Kesehatan Anak Rumah Sakit Umum Dr. Saiful Anwar Malang \\ ${ }^{2}$ Laboratorium IImu Penyakit Jantung dan Kedokteran Vaskuler Rumah Sakit Umum Dr. Saiful Anwar Malang
}

\begin{abstract}
ABSTRAK
Anak-anak dengan penyakit kronis memiliki risiko lebih tinggi mengalami gangguan kualitas hidup dibandingkan anak sehat. Tujuan dari penelitian ini adalah untuk menilai kualitas hidup anak dengan penyakit jantung menggunakan PedsQL (Pediatrics Quality of Life). Sampel dipilih secara konsekutif diperoleh dari semua anak dengan penyakit jantung berusia 218 tahun, yang dirawat di Rumah Sakit Umum Dr. Saiful Anwar dari periode Januari sampai Maret 2012. Semua pasien dengan kondisi medis komorbid atau dengan gangguan perkembangan saraf dieksklusi sehingga didapatkan sampel pada usia 2-4 tahun, PedsQL memiliki skor terendah pada kecemasan $(50,0 \pm 39,03)$. Pada usia 5-7 tahun, nilai terendah adalah fungsi dari komunikasi, sementara berdasar laporan orangtua, skor rendah pada masalah kecemasan kontrol dan ketakutan saat mengambil obat. Pada usia 8-12 tahun, skor terendah pada kemampuan pasien dalam melakukan aktivitas fisik. Pada usia 13-18 tahun, skor terendah pada masalah kognitif konsentrasi dan kemampuan belajar. Tidak ada perbedaan signifikan kualitas hidup pasien menurut umur dan jenis penyakit jantung. Ada perbedaan yang signifikan antara jenis penyakit jantung (bawaan atau diperoleh) dengan status gizi pasien $(p=0,03)$. Kualitas hidup pasien dengan penyakit jantung lebih rendah daripada populasi normal karena gangguan fisik dan psikososial fase negara kronis.
\end{abstract}

Kata Kunci: Anak, kualitas hidup, penyakit jantung

\begin{abstract}
Children with chronic illnesses have a higher risk of impaired quality of life than healthy children. The purpose of this study was to assess the quality of life of children with heart disease using PedsQL (Pediatrics Quality of Life) Samples were consecutively selected from all children with heart disease aged 2-18 years, who were treated at Saiful Anwar General Hospital from period of January to March, 2012. All patients with comorbid medical conditions or with neurodevelopmental disorders were excluded. At the age of 2-4 years, PedsQL have the lowest scores on anxiety (50,0 \pm 39,03). At the age of 5-7 years, the lowest score is a function of communication, while in parent-report the lower scores on the anxiety problems of control and fear when taking medication. At the age of 8-12 years, the lowest scores on the ability of patients heart problems in carrying out physical activity. At the age of 13-18 years, the lowest scores on the cognitive problems of concentration and learning ability. There is no significant difference of quality of life of patients by age and the type of heart disease. There is a significant difference between the types of heart disease (congenital or acquired) by the patient's nutritional status $(p=0,03)$. Quality of life of patients with heart disease is lower than the normal population due to physical and psychosocial distress of chronic state.
\end{abstract}

Keywords: Children, heart disease, quality of life

Jurnal Kedokteran Brawijaya, Vol. 27 No. 1, Februari 2012; Korespondensi: Ariani. Laboratorium Ilmu Kesehatan Anak Rumah Sakit Umum Dr. Saiful Anwar Malang, Jl. Jaksa Agung Suprapto No.2 Malang Tel. (0341) 366242 Email: arianidr@yahoo.com 


\section{PPENDAHULUAN}

Diperkirakan satu juta anak di Amerika hidup dengan penyakit jantung bawaan (PJB). Angka kejadian PJB di Indonesia adalah 8 tiap 1000 kelahiran hidup. Perkembangan yang signifikan dalam tatalaksana kelainan kardiovaskuler baik dengan medikamentosa maupun pembedahan telah meningkatkan angka harapan hidup pasien. Sekitar $80-90 \%$ anak dengan kelainan kardiovaskuler mampu bertahan hidup sampai dewasa. Penatalaksanaan PJB tidak hanya ditujukan untuk peningkatan angka harapan hidup tetapi juga memperhatikan kualitas hidup pasiena (1).

Penelitian terdahulu mengenai kelainan kardiovaskuler anak sebagian besar berfokus pada luaran klinis berupa mortalitas, morbiditas, dan status kesehatan termasuk sekuele anatomik atau hemodinamik, sekuele elektrofisiologi dan kapasitas latihan setelah intervensi bedah. Dengan perkembangan usia harapan hidup luaran kllinis berupa morbiditas dan mortalitas tidaklah cukup $(2,3)$. Parameter kualitas hidup anak menjadi luaran klinis yang penting. Aspek yang terkandung di dalamnya mencakup aspek kesehatan fisik, psikologis, dan fungsi sosial. Pendekatan multidimensional ini sejalan dengan konsep WHO mengenai kesehatan yaitu bukan hanya tdak adanya penyakit tetapi harus disertai adanya kesejahteraan fisik, mental, dan sosial.

Anak-anak dengan penyakit kronik diketahui memiliki risiko lebih tinggi terjadinya gangguan kualitas hidup dibanding anak sehat. Berbagai tekanan dapat mempengaruhi perkembangan psikologis anak, antara lain yang berhubungan dengan penyakitnya (keharusan minum obat, rasa nyeri, sesak, tidak nyaman dengan penampilan fisik ) serta tekanan lain seperti lingkungan, dan tugas-tugas sekolah. Menurut Eisser, anak dengan penyakit kronik lebih banyak mengalami depresi dibandingkan perilaku agresif (3).

Health-related Quality of Life merefleksikan persepsi anak maupun keluarga mengenai dampak penyakit serta terapinya terhadap kehidupan sehar-harinya. Dampak dari penyakit dan terapi terhadap keluarga sangat dipengaruhi oleh kemampuan adaptasi anak terhadap kondisi penyakitnya. Kemampuan keluarga dalam mengatasi berbagai tekanan tampaknya mempengaruhi kualitas hidup anak (4). Pediatrics Quality of Life (PedsQL) Cardiac Module merupakan suatu instrumen multidimensional untuk menilai pengaruh penyakit jantung anak terhadap kualitas hidup anak maupun keluarganya. Kuesioner ini dapat menilai kualitas hidup berdasarkan berbagai macam aspek antara lain kapasitas fisik, emosi dan kecemasan, fungsi sosial, kemampuan kognitif dan persepsi mengenai penampilan fisik. Tujuan dari penelitian ini adalah untuk menilai kualitas hidup anak dengan penyakit jantung,perbedaan kualitas hidup pasien penyakit jantung berdasarkan usia, jenis penyakit jantung, dan status gizi.

\section{METODE}

Sampel diperoleh dengan metode konsekutif yaitu semua anak dengan penyakit jantung usia 2-18 tahun yang dirawat di ruang rawat inap maupun klinik rawat jalan penyakit jantung anak periode Januari-Maret 2012. Kesediaan pasien dan orang tuanya untuk menjadi sampel pengisian kuisioner ini diperoleh secara lisan dan tertulis (informed consent). Semua pasien dengan kondisi komorbid medik atau dengan kelainan neurodevelopmental dieksklusi. Seluruh sampel diperoleh dari klinik rawat jalan yaitu sebanyak 11 pasien penyakit jantung bawaan maupun didapat (patient-report) dan 14 orang tua pasien (parent-report). Wawancara dilakukan selama menunggu pemeriksaan oleh dokter. Tidak didapatkan pasien rawat inap yang memenuhi persyaratan usia.

Penelitian ini menggunakan kuisioner The PedsQL Cardiac Module versi 3.0 untuk menilai kualitas hidup pasien berdasar persepsi anak maupun orang tua. Kuisioner ini terdiri dari 23 pertanyaan yang menilai masalah jantung dan terapi, penampilan fisik, kecemasan, kognitif dan komunikasi selama satu bulan terakhir. PedsQL Cardiac Module tersedia untuk berbagai kelompok usia yaitu usia 2-4 tahun, 5-7 tahun, 8-12 tahun dan 13-18 tahun. Untuk pasien usia 5-18 tahun tersedia dua macam kuisioner yaitu kuisioner untuk orang tua dan untuk pasien sendiri, sedangkan pasien usia 2-4 tahun hanya terdiri dari kuisioner untuk orang tua, tidak ada kuesioner untuk anak umur 2-4 tahun karena anak masih belum komunikatif. Penilaian dalam setiap item kuesioner diberikan dengan angka 0,1,2,3,4 (0: tidak pernah, 1: hampir tidak pernah, 2: kadang-kadang, 3: sering, 4: hampir selalu), yang kemudian dikonversikan dalam skor dengan rentang 0-100 (0: 100, 1: 75, 2: 50, 3: 25, 4: 0). Skor dijumlah lalu dibagi total pertanyaan yang terjawab. Makin tinggi nilai skor yang diperoleh makin baik kualitas hidup pasien $(4,5)$.

Selain PedsQL cardiac module, untuk pasien usia 8-12 tahun juga digunakan PedsQL Inventory versi 4.0 yang berisi 23 pertanyaan untuk menilai fungsi fisik, emosi, sosial dan sekolah. Nilai rata-rata populasi normal didapatkan dari database PedsQL parent-report untuk anak sehat tanpa penyakit kronik yang dipublikasikan oleh Varni dkk pada tahun 2003. Dikatakan terjadi gangguan kualitas hidup bila nilai rata-rata dibawah 1 Standar Deviasi (SD) rata-rata populasi normal.

Karakteristik dasar pasien berupa jenis kelamin, usia, diagnosis, lama diagnosis, status gizi dicatat kemudian disajikan dalam tabel deskriptif. Perbedaan kualitas hidup pasien dengan penyakit jantung dengan populasi normal dianalisis menggunakan metode deskriptif. Perbedaan kualitas hidup pasien penyakit jantung berdasarkan usia dianalisis menggunakan metode One Way ANOVA. Pengaruh jenis penyakit jantung (bawaan maupun didapat) terhadap kualitas hidup pasien berdasarkan persepsi anak dan orang tua dianalisis menggunakan uji independent sample $T$ test. Pengaruh jenis penyakit jantung terhadap status gizi dianalisis menggunakan uji Kolmogorov Smirnov karena merupakan data kategorikal dan tidak memenuhi syarat uji Chi-Square. Program statistik yang digunakan adalah SPSS versi 17.0

\section{HASIL}

Sampel pasien pada penelitian ini sebagian besar berusia 8-12 tahun dan berjenis kelamin perempuan. Pada sampel orang tua didapatkan sebagian besar berusia 20-40 tahun. Berdasarkan data parent report, diagnosis terbanyak adalah penyakit jantung didapat, dan terdiagnosa sesudah menderita 1-5 tahun. Kelainan ikutan hanya didapatkan pada sebagian kecil pasien, demikian juga gizi kurang hanya ditemukan pada 5 pasien (Tabel 1). 
Tabel 1. Karakteristik dasar sampel

\begin{tabular}{|c|c|c|}
\hline \multirow{2}{*}{$\begin{array}{c}\text { Karakteristik } \\
\text { Pasien (self report) }\end{array}$} & \multicolumn{2}{|c|}{ N \% } \\
\hline & 11 & 100 \\
\hline 5-7 tahun & 2 & 18,2 \\
\hline $8-12$ tahun & 7 & 63,6 \\
\hline 13-18 tahun & 2 & 18,2 \\
\hline Jenis kelamin : & 11 & 100 \\
\hline Laki-laki & 4 & 36,4 \\
\hline Perempuan & 7 & 63,6 \\
\hline Orangtua/pengasuh (parent-report) & 14 & 100 \\
\hline Usia 20-40 tahun & 10 & 71,4 \\
\hline Usia 41-79 tahun & 4 & 28,6 \\
\hline Diagnosis (parent-report) & 14 & 100 \\
\hline Penyakit jantung didapat & 9 & 64,3 \\
\hline PJR eksaserbasi akut & 1 & 7,1 \\
\hline PR & 1 & 7,1 \\
\hline $\mathrm{Ml}$ & 3 & 21,3 \\
\hline MSI & 1 & 7,1 \\
\hline DR akut & 3 & 21,3 \\
\hline Penyakit Jantung bawaan & 5 & 35,7 \\
\hline PDA & 1 & 7,1 \\
\hline Kombinasi & 4 & 28,5 \\
\hline Adanya penyakit penyerta & 3 & 21,3 \\
\hline House dust mite allergy & 1 & 7,1 \\
\hline Epilepsi & 1 & 7,1 \\
\hline Kolelitiasis & 1 & 7,1 \\
\hline Lama terdiagnosis & 14 & 99,9 \\
\hline$<1$ tahun & 1 & 7,1 \\
\hline 1-5 tahun & 11 & 78,6 \\
\hline$>5$ tahun & 2 & 14,2 \\
\hline Status gizi & 14 & 99,9 \\
\hline Gizi kurang & 5 & 35,7 \\
\hline Gizi baik & 8 & 57,1 \\
\hline Gizi lebih & 1 & 7,1 \\
\hline
\end{tabular}

Hampir semua pertanyaan terjawab oleh sampel. Berdasarkan hasil self-report maupun parent-report, kualitas hidup pasien penyakit jantung lebih rendah daripada populasi normal pada fungsi fisik, emosi, sosial maupun sekolah (Tabel 2).

Terdapat perbedaan permasalahan kualitas hidup penderita pada kelompok umur yang berbeda. Pada usia 2-4 tahun skor terendah ada pada kecemasan $(50,0 \pm 39,03)$, yaitu ketakutan anak saat kontrol serta minum obat. Pada usia 5-7 tahun skor terendah patientreport adalah fungsi komunikasi yaitu kesulitan untuk mengungkapkan masalahnya pada orang lain, sedangkan menurut parent-report skor terendah ada pada masalah kecemasan yaitu ketakutan saat kontrol dan minum obat. Skor terendah ada pada kemampuan pasien dalam menjalankan aktifitas fisik ditemukan pada usia 8-12 tahun. Pada usia 13-18 tahun skor terendah ada pada masalah kognitif yaitu kemampuan konsentrasi serta belajar. Meskipun terdapat perbedaan secara umum nilai rata-rata tiap permasalahan masih menunjukkan nilai yang baik yaitu di atas 70 . Tidak terdapat perbedaan bermakna kualitas hidup pasien berdasarkan usia menurut selfreport $(p=0,428)$ maupun parent-report $(p=0,196)$. Perbedaan kualitas hidup menurut jenis penyakit jantung bawaan tidak ditemukan baik berdasarkan self-report maupun parent-report $(p=0,451$ dan $p=0,356)$. Status gizi pasien $(p=0,03)$ berhubungan dengan jenis penyakit jantung (bawaan maupun didapat).

Tabel 2. Perbandingan skor PedsQL Inventory pasien Usia 812 tahun dengan populasi normal

\begin{tabular}{llcccc}
\hline Skala & & \multicolumn{2}{c}{$\begin{array}{c}\text { Sampel } \\
\text { Penderita } \\
\text { Penyakit } \\
\text { Jantung }\end{array}$} & \multicolumn{2}{c}{$\begin{array}{c}\text { Sampel } \\
\text { Populasi } \\
\text { Normal }\end{array}$} \\
\cline { 3 - 6 } $\begin{array}{c}\text { Mean } \\
\text { report }\end{array}$ & & SD & Mean & SD \\
\hline & Skor total & 67,92 & 16,35 & 84,38 & 12,85 \\
& Fungsi fisik & 65,98 & 17,86 & 87,98 & 13,77 \\
& Fungsi emosi & 67,85 & 23,06 & 79,31 & 18,13 \\
& Fungsi Sosial & 77,5 & 16,04 & 86,15 & 16,53 \\
& Fungsi Sekolah & 55,41 & 28,91 & 81,89 & 16,21 \\
Parent report & & & & \\
& Skor total & 68,97 & 16,29 & 80,48 & 16,28 \\
& Fungsi fisik & 67,85 & 17,65 & 82,91 & 20,56 \\
& Fungsi emosi & 65,71 & 28,92 & 79,66 & 17,84 \\
& Fungsi Sosial & 83,33 & 20,89 & 81,39 & 20,93 \\
& Fungsi Sekolah & 58,33 & 18,35 & 76,42 & 19,71
\end{tabular}

\section{DISKUSI}

Penanganan pasien anak dengan penyakit jantung bawaan maupun didapat harus menyeluruh termasuk dukungan terhadap keluarga dalam beradaptasi dengan keadaan kronis akibat penyakit tersebut. Tujuan penanganan adalah untuk menurunkan morbiditas, mortalitas serta meningkatkan kualitas hidup pasien dan keluarganya.

Berdasarkan penilaian PedsQL Inventory usia 8-12 tahun baik self-report maupun parent-report didapatkan kualitas hidup penderita penyakit jantung lebih rendah daripada populasi normal baik pada fungsi fisik, emosi, sosial maupun sekolah. Keadaan kronik akibat penyakit jantung sangat berpengaruh terhadap kehidupan sehari-hari pasien dan keluarga misalnya akibat adanya pembatasan aktifitas fisik pasien, rutinitas minum obat, keharusan kontrol rutin atau rawat inap. Pada anak yang lebih besar dapat timbul perasaan sedih atau marah karena harus menjalani semua hal tersebut. Anak dapat menjadi rendah diri dan menarik diri dari pergaulan. Orang tua dapat mengalami distres akibat penyakit jantung yang diderita anaknya, terutama terkait dengan masalah biaya pengobatan, kesulitan membujuk anak agar mau minum obat atau kekhawatiran akan masa depan anak (6). Dokter 
yang merawat harus menunjukkan empati dan harus mampu memberi keterangan yang jelas serta meluruskan hal-hal yang dipersepsikan secara salah oleh orang tua. Selain itu orang tua harus diberi kesempatan yang cukup untuk mengekspresikan perasaannya. Dukungan psikososial misalnya pertemuan kelompok orang tua dengan keadaan yang sama dapat menjadi tempat untuk saling berbagi pengalaman, memecahkan persoalan serta membantu orang tua dalam beradaptasi dengan keadaan kronik akibat penyakit jantung anak (6).

Pada usia 2-4 tahun skor terendah ada pada kecemasan saat terapi, yaitu ketakutan anak saat kontrol serta minum obat, karena kedua saat tersebut merupakan saat yang tidak nyaman untuk pasien. Keharusan bertemu dengan orang-orang yang baru dikenal saat di rumah sakit serta berbagai pemeriksaan baik invasif maupun non invasif dapat menimbulkan trauma tersendiri bagi pasien (6).

Pada usia 5-7 tahun skor terendah self-report adalah fungsi komunikasi. Pada usia ini anak masih belum mampu mengungkapkan masalah atau keluhannya secara jelas pada orang lain, atau bahkan takut berbicara terutama pada orang yang belum dikenal misalnya kepada dokter atau petugas medis lainnya. Selain itu kendala bahasa dapat menjadi faktor penyebab yang lainnya. Tipe kepribadian juga mempengaruhi kemampuan adaptasi anak terhadap kondisi penyakit serta stresor yang berasal dari lingkungan. Menurut parent-report skor terendah ada pada masalah kecemasan, namun skor yang diperoleh masih cukup tinggi. Kecemasan yang dimaksud utamanya saat kontrol dan minum obat. Seperti halnya pada anak yang lebih kecil, rutinitas minum obat dapat menjadi hal yang kurang nyaman serta menimbulkan trauma tersendiri. Pada usia ini anak sudah mulai dapat diberikan pengertian mengenai manfaat terapi tersebut serta risiko jika dia menolak, sehingga tidak terlalu menimbulkan masalah.

Pada usia 8-12 tahun skor terendah ada pada masalah jantung yaitu kemampuan pasien dalam menjalankan aktifitas fisik. Keterbatasan kemampuan fisik anak dengan penyakit jantung bisa disebabkan oleh dua hal yaitu rendahnya tingkat energi pasien atau memang aktifitas pasien dibatasi secara sengaja. Rendahnya tingkat energi anak dengan penyakit jantung disebabkan oleh buruknya asupan makanan dan absorbsi nutrisi dari saluran cerna, meningkatnya pemakaian energi melalui metabolisme serta adanya infeksi saluran nafas yang berulang. Berdasakan kuisioner ini skor rata-rata masih cukup baik yaitu $77,03 \pm 10,72$ dan $79,18 \pm 15,22$. Hal ini mungkin disebabkan anak sudah dalam keadaan terkontrol oleh obat sehingga meningkatkan kapasitas fungsionalnya, atau karena sebagian besar pasien sudah menjalani pembatasan aktifitas fisik karena umumnya orang tua khawatir anaknya mengalami pemburukan gejala selama menjalani aktifitas fisik. Bahkan terdapat seorang anak yang sengaja dilarang sekolah dengan alasan khawatir terjadi pemburukan gejala. Sikap orang tua yang overprotective justru dapat menyebabkan anak menjadi kurang percaya diri dan ikut mudah cemas. Sebenarnya sebagian besar anak dengan penyakit jantung masih diperbolehkan untuk menjalani aktifitas fisik secara normal (7). Orang tua serta guru harus mendapat penjelasan mengenai manfaat aktifitas fisik tersebut baik secara medis maupun psikososial. Pada usia ini anak juga memiliki kebutuhan lain misalnya berteman, keinginan memperoleh kebebasan, memperoleh ilmu pengetahuan.

The American Heart Association tahun 1986 telah mengeluarkan rekomendasi mengenai aktifitas fisik berdasarkan diagnosis. Rekomendasi tersebut harus dipertimbangkan secara individual dan evaluasi keadaan pasien secara komprehensif harus dilakukan sebelum membuat keputusan mengenai aktifitas yang akan direkomendasikan. Ekokardiografi dapat memberikan informasi mengenai anatomi kardiovaskuler, lesi residual, fungsi katub dan ventrikel. Uji latih jantung juga dapat memberi informasi yang objektif mengenai kemampuan fungsional jantung, perubahan hemodinamik selama aktifitas fisik (keluhan, tekanan darah dan irama jantung) (8).

Pada usia 13-18 tahun skor terendah ada pada masalah kognitif yaitu kemampuan konsentrasi serta belajar. Pada usia ini anak memasuki sekolah menengah beban pelajaran di sekolah relatif makin berat. Menurut meta analisis yang dilakukan oleh Karsdorp tahun 2007 disebutkan bahwa pada anak dengan penyakit jantung fungsi kognitif dapat dipengaruhi oleh jenis dan derajat keparahan penyakit jantung. Pada ASD (Atrial Septal Defect), VSD (Ventricle Septal Defect) dan TGA (Transposition of Great Arteries) umumnya kemampuan kognitif masih dalam batas normal. Sebaliknya pada kelainan jantung berat misalnya hypoplastic left heart syndrome berhubungan dengan fungsi kognitif yang rendah. Rendahnya fungsi kognitif pada kelainan jantung yang berat mungkin berhubungan dengan adanya kelainan otak yang mungkin menyertai kelainan bawaan, rendahnya perfusi ke otak serta adanya kejang karena hipoksia (6). Pada penelitian ini rata-rata nilai kognitif masih cukup baik karena sampel yang terekrut tidak ada yang menderita kelainan jantung berat.

Hasil uji One Way ANOVA menunjukkan tidak terdapat perbedaan bermakna kualitas hidup pasien berdasarkan usia menurut self report maupun parent-report. Hal ini mungkin disebabkan semua pasien dalam keadaan terkontrol (kompensata). Menurut literatur terdapat berbagai faktor yang berpengaruh terhadap kualitas hidup pasien dengan penyakit jantung antara lain derajat keparahan penyakit, keadaan sosial ekonomi, tipe kepribadian serta tingkat pendidikan orang tua $(7,10,11,12)$. Pada pengisian kuisioner ini tidak dianalisis mengenai pengaruh keadaan sosial ekonomi, tipe kepribadian serta tingkat pendidikan orang tua terhadap kualitas hidup anak.

Berdasarkan uji $t$ tidak berpasangan, tidak terdapat perbedaan bermakna pada skor total PedsQL self-report maupun parent-report berdasarkan jenis penyakit jantung (bawaan atau dapatan). Hal ini mungkin disebabkan oleh pasien sudah dalam keadaan terkontrol oleh obat. Selain itu mungkin juga berhubungan dengan lama diagnosis yaitu rata-rata 1-5 tahun adaptasi pasien maupun keluarga terhadap keadaan kronik akibat penyakit jantung sudah lebih baik (13-15).

Berdasarkan uji Kolmogorov Smirnov terdapat perbedaan bermakna antara jenis penyakit jantung (bawaan maupun didapat) dengan status gizi pasien, yaitu pasien yang terdiagnosis penyakit jantung bawaan mengalami gizi kurang. Anak dengan penyakit jantung bawaan dapat mengalami gizi kurang karena buruknya asupan makanan dan absorbsi nutrisi dari saluran cerna, meningkatnya 
kebutuhan energi serta adanya infeksi saluran nafas berulang. Stres pada anak juga dapat berpengaruh terhadap nutrisi misalnya karena nafsu makan menurun. Perlunya restriksi cairan dapat memperburuk asupan kalori lebih lanjut. Anak dengan penyakit jantung sianotik keadaan hipoksia juga berkontribusi terhadap masalah pertumbuhan. Frekuensi menyusui yang lebih sering dengan durasi lebih pendek, atau pemberian susu formula dengan volume yang lebih sedikit namun frekuensi lebih sering dapat bermanfaat untuk menurunkan kebutuhan energi anak. Jika anak atau bayi tidak toleran terhadap peningkatan volume atau harus dilakukan restriksi cairan maka fortifikasi zat gizi pada susu dapat bermanfaat untuk mencegah kekurangan kalori maupun nutrisi lainnya (8).

Peningkatan kualitas hidup anak dengan penyakit jantung dapat dilakukan dengan beberapa cara antara lain pemberian diet yang seimbang dan tidak terlalu membebani metabolisme tubuh, pencegahan anemia, pemberian vaksinasi yang lengkap untuk mencegah berbagai penyakit yang dapat mengeksaserbasi gagal jantung. Jika anak hendak menjalani prosedur invasif

\section{DAFTAR PUSTAKA}

1. Madiyono B. Kardiologi Anak Masa Lampau, Kini dan Masa Mendatang: Perannya dalam Pencegahan dan Penanggulangan Penyakit Kardiovaskular. Pidato Pengukuhan Guru Besar Dalam Bidang IImu Kesehatan Anak, FKUI, Jakarta, 11 Juni 1997. Jakarta: Lembaga Penerbit UI; 1997.

2. Uzark K, Jones K, Slusher J, Limbers CA, Burwinkle TM, and Varni JW. Quality of Life in Children with Heart Disease as Perceived by Children and Parents. Pediatrics. 2008; 121: e1060-1067.

3. Eiser C. Children with Cancer: The Quality of Life. New Jersey: Lawrence Erlbaum Associates Publisher; 2004.

4. Marino BS, Tomlinson RS, Drotar D, et al. Quality of Life Concerns Differ Among Patients, Parents, and Medical Providers in Children and Adolescents with Congenital and Acquired Heart Disease. Pediatrics. 2009; 123(4): 708-e715.

5. Higginson IJ and Carr AJ. Measuring Quality of Life: Using Quality of Life Measures in the Clinical Setting. British Medical Journal. 2001; 322(7297): 1297-1300.

6. Kasdorp PA, Everaerd W, Kindt M, and Mulder BJM. Psychological and Cognitive Functioning in Children and Adolescents with Congenital Heart Disease: $A$ Meta-Analysis. Journal of Pediatric Psychology. 2007; 32(5): 527-541.

7. Nousi D and Christou A. Factors Affecting the Quality of Life in Children with Congenital Heart Disease. Health Science Journal. 2010; 4(2): 94-100. hendaknya diberikan antibiotik profilaksis untuk mencegah endokarditis infeksiosa (7). Kelemahan penelitian ini adalah jumlah subjek yang sedikit, semua berasal dari poliklinik rawat jalan sehingga kurang mencerminkan kualitas hidup saat pasien mengalami dekompensata. Adanya faktor-faktor lain seperti jenis obat yang diminum, derajat keparahan penyakit, kepatuhan minum obat, frekuensi menderita sakit yang berpengaruh terhadap kualitas hidup tidak dianalisis sehingga dapat menjadi bias.

Hasil penelitian ini menunjukkan bahwa kualitas hidup anak dengan penyakit jantung lebih rendah daripada populasi normal baik pada fungsi fisik, emosi, sosial maupun sekolah disebabkan oleh adanya distres fisik maupun psikososial akibat keadaan kronik. Terdapat perbedaan permasalahan menurut kelompok umur tertentu meskipun tidak terdapat perbedaan bermakna kualitas hidup pasien berdasarkan usia dan jenis penyakit menurut self-report maupun parent-report. Pasien dengan penyakit jantung bawaan cenderung mempunyai status gizi rendah.

8. Cheung Y. Fundamentals of Congenital Heart Disease. Singapore: Saunders Elsevier Publisher; 2006; p. 137350.

9. Cohen M, Mansoor D, Langut H, and Lorber A. Quality of Life, Depressed Mood and Self Esteem in Adolescents with Heart Disease. Psychosomatic Medicine. 2007; 69(4): 313-318.

10. Wright $\mathrm{M}$ and Nolan T. Impact of Cyanotic Heart Disease on School Performance. Archives and Disease in Childhood. 1994; 71(1): 64-70.

11. Wray J and Sensky T. Congenital Heart Disease and Cardiac Surgery in Childhood: Effects of Cognitive Function and Academic Ability. Heart. 2001; 85(6): 687-691.

12. Daliena L, Mapelli D, and Volpe B. Measurement of Cognitive Outcome and Quality of Life in Congenital Heart Disease. Heart. 2006; 92: 569-574.

13. Utens EM, Verhulst FC, Duivenvoorden HJ, Meijboom FJ, Erdman RA, and Hess J. Prediction of Behavioural and Emotional Problems in Children and Adolescent with Operated Congenital Heart Disease. European Heart Journal. 1998; 19(5): 801-807.

14. Van Rijen EH, Utens EM, Roos-Hesselink JW, et al. Longitudinal Development of Psychopathology in an Adult Congenital Heart Disease Cohort. International Journal of Cardiology. 2005: 99(2); 315-323.

15. Janus M, Goldbergs. Treatment Caracteristics of Congenital Heart Disease and Behaviour Problems of Parents and Healthy Siblings. Journal of Paediatrics and Child Health. 1997; 33(3): 219-225. 